\title{
Molecular Characterization of Ferulate 5-Hydroxylase Gene from Kenaf (Hibiscus cannabinus L.)
}

\author{
Jonggeun Kim, ${ }^{1}$ Bosung Choi, ${ }^{1}$ Young-Hwan Park, ${ }^{1}$ Byoung-Kwan Cho, ${ }^{2}$ Hyoun-Sub Lim, ${ }^{3}$ \\ Savithiry Natarajan, ${ }^{4}$ Sang-Un Park, ${ }^{5}$ and Hanhong Bae ${ }^{1}$
}

${ }^{1}$ School of Biotechnology, Yeungnam University, Gyeongsan 712-749, Republic of Korea

${ }^{2}$ Department of Biosystems and Machinery Engineering, Chungnam National University, Daejeon 305-764, Republic of Korea

${ }^{3}$ Department of Applied Biology, Chungnam National University, Daejeon 305-764, Republic of Korea

${ }^{4}$ Soybean Genomics and Improvement Laboratory, US Department of Agriculture, Agricultural Research Service, 10300 Baltimore Avenue, Beltsville, MD 20705, USA

${ }^{5}$ Department of Crop Science, Chungnam National University, Daejeon 305-754, Republic of Korea

Correspondence should be addressed to Hanhong Bae; hanhongbae@ynu.ac.kr

Received 11 July 2013; Accepted 16 August 2013

Academic Editors: S. Iben, H. Okamura, P. Saha, and P. Vito

Copyright (C) 2013 Jonggeun Kim et al. This is an open access article distributed under the Creative Commons Attribution License, which permits unrestricted use, distribution, and reproduction in any medium, provided the original work is properly cited.

\begin{abstract}
The purpose of this study is to clone and characterize the expression pattern of a $F 5 H$ gene encoding ferulate 5-hydroxylase in the phenylpropanoid pathway from kenaf (Hibiscus cannabinus L.). Kenaf is a fast-growing dicotyledonous plant valued for its biomass. F5H, a cytochrome P450-dependent monooxygenase (CYP84), is a key enzyme for syringyl lignin biosynthesis. The full length of the $\mathrm{F5H}$ ortholog was cloned and characterized. The full-length $\mathrm{F} 5 \mathrm{H}$ ortholog consists of a 1,557-bp open reading frame (ORF) encoding 518 amino acids (GenBank Accession number JX524278). The deduced amino acid sequence showed that kenaf F5H had the highest similarity (78\%) with that of Populus trichocarpa. Transcriptional analysis of F5H ortholog was conducted using quantitative real-time PCR during the developmental stages of various tissues and in response to various abiotic stresses. The highest transcript level of the $\mathrm{F} 5 \mathrm{H}$ ortholog was observed in immature flower tissues and in early stage (6 week-old) of stem tissues, with a certain level of expression in all tissues tested. The highest transcript level of $F 5 \mathrm{H}$ ortholog was observed at the late time points after treatments with $\mathrm{NaCl}(48 \mathrm{~h})$, wounding $(24 \mathrm{~h})$, cold $(24 \mathrm{~h})$, abscisic acid $(24 \mathrm{~h})$, and methyl jasmonate $(24 \mathrm{~h})$.
\end{abstract}

\section{Introduction}

Kenaf (Hibiscus cannabinus L.) is an annual dicotyledonous and a fast-growing herbaceous plant, spanning a wide ecological habitat from temperate to tropical areas [1]. Kenaf is regarded as the third largest fiber crop following cotton and jute and is indispensible for pulp and paper industries [2,3]. Since kenaf has large ranging habitats and fast growth rate, it has great potential for use in biomass production [4-6]. Lignin is an aromatic heteropolymer that is predominantly found in the secondary plant cell walls with cellulose and hemicellulose and is the second most abundant biopolymer on earth after cellulose [7-9]. It provides rigidity to the plant cell wall and hydrophobicity to the vascular system of plants. In addition, lignin is highly associated with the plant defense mechanisms against biotic and abiotic stresses [7-9]. However, lignin is one of the major obstructions in the conversion of plant biomass to pulps, papers, or biofuels $[8,10]$. Lignin protects polysaccharides in plant cell walls from microbial degradation. As lignin is strongly bound to polysaccharides, cellulose and hemicellulose polymers are able to get only a limited access to microbial hydrolytic enzymes such as cellulases. For the efficient use of polysaccharides in pulps or biofuels, lignin should be reduced or removed. In addition, the residual products generated during the removal of lignin can inhibit the subsequent processes of saccharification and fermentation. The removal of lignin from plant biomass is a costly process and generates environmental pollutants [10-12]. These shortcomings of the presence of lignin prompted many scientists to develop 
genetically modified plants with less lignin content or an altered lignin component for its easy degradation [7, 8, 13]. Lignin is synthesized through the phenylpropanoid pathway [14]. There are two major steps of lignin biosynthesis in plants. In the first step, three hydroxycinnamyl alcohol monomers ( $p$-coumaryl, coniferyl, and sinapyl alcohols) are synthesized through the phenylpropanoid pathway. In the second step, these alcohol monomers are integrated into the lignin polymers by peroxidase and laccase during polymerization to form $\rho$-hydroxyphenyl $(\mathrm{H})$, guaiacyl $(\mathrm{G})$, and syringyl $(\mathrm{S})$ units, respectively $[15,16]$. Among the three units, the $S$ unit is relatively unbranched and has a higher degree of degradability [14]. The biomass of kenaf fibers is favorable for delignification because these fibers contain less amount of lignin and have a high $\mathrm{S} / \mathrm{G}$ ratio with small amounts of $\mathrm{H}$ unit (S 83.3\%, G 15.4\%, and H 1.3\%) [17, 18]. Many attempts have been made to modify the content and composition of lignin in order to increase pulping efficiency. Upregulation of $\mathrm{F} 5 \mathrm{H}$ increases the $\mathrm{S} / \mathrm{G}$ ratio $[10,13]$. $\mathrm{F} 5 \mathrm{H}$, a cytochrome P450-dependent monooxygenase (CYP84), is specifically required for the synthesis of S lignin [14]. It catalyzes the 5hydroxylation of coniferaldehyde and/or coniferyl alcohol in the phenylpropanoid pathway. Upregulation of $F 5 H$ in poplar tree was found to increase the $S / G$ ratio that subsequently led to increased pulping efficiency [19]. Conversely, downregulation of $F 5 H$ in alfalfa caused a decrease in the S/G ratio [13]. Arabidopsis transgenic lines overexpressing $\mathrm{F} 5 \mathrm{H}$ showed that it contained S lignin in a larger proportion (92\%) [20]. Therefore, $\mathrm{F} 5 \mathrm{H}$ is a key enzyme involved in synthesizing monolignol sinapyl alcohol and, ultimately, S lignin moieties. In this study, we cloned and characterized $\mathrm{F} 5 \mathrm{H}$ ortholog in kenaf to investigate the expression patterns of $\mathrm{F} 5 \mathrm{H}$ ortholog in various developmental stages, in different tissues, and under various abiotic stresses such as $\mathrm{NaCl}$, wounding, cold, $\mathrm{ABA}, \mathrm{MeJA}$, and drought using quantitative real-time PCR (QPCR).

\section{Materials and Methods}

2.1. Plant Materials. Dr. Si-Yong Kang (Advanced Radiation Technology Institute, Korea Atomic Energy Research Institute, Jeongeup, Korea) generously provided kenaf seeds (Hibiscus cannabinus L., C-9) that were originally from Russia (GenBank of Korea Rural Development Administration IT number 202789). Seeds were germinated in small pots filled with a sterile nonsoil mixture (Tobietec, Chungbuk, Korea). Kenaf seedlings were grown for up to 4 weeks in a growth room, watered twice a week, and maintained under the following growth condition: 16 -h light/8-h dark, $22^{\circ} \mathrm{C}$, and $100 \mu \mathrm{mol} \mathrm{m}^{-2} \mathrm{~s}^{-1}$ light intensity. After 4 weeks in the growth room, kenaf seedlings were transplanted into larger pots $(20$ $\mathrm{cm}$ diameter) filled with nonsoil mixture and were grown in a greenhouse for up to 20 weeks with watering twice a week. Various tissues (roots, stems, leaves, petioles, and flowers) were harvested from 16-week-old kenaf plants during midday of light length. Harvested samples were immediately frozen in liquid nitrogen and stored at $-80^{\circ} \mathrm{C}$. Leaf tissues were harvested at three development stages: (1) young leaf (YL),
$<2 \mathrm{~cm}$ long; (2) immature leaf (IL), 3-5 cm long; and (3) mature leaf $(\mathrm{ML}),>9 \mathrm{~cm}$ long. In addition, flower samples were harvested at three development stages: (1) young flower (YF), unopened green flower, $<2 \mathrm{~cm}$ long with green sepal; (2) immature flower (IF), unopened white flower, $>3 \mathrm{~cm}$ long with green sepal; and (3) mature flower, open white flower.

2.2. Stress Treatments. Three-week-old plants, grown in the growth room as previously described, were treated with diverse abiotic stresses. Stem tissues were harvested for RNA extraction. For the wounding treatment, stem tissues were cut twice longitudinally with scissors. For cold treatment, plants were put into a cold room under following growth conditions: $16 \mathrm{~h}$ light $/ 8 \mathrm{~h}$ dark, $10^{\circ} \mathrm{C}$, and $100 \mu \mathrm{mol} \mathrm{m}{ }^{-2} \mathrm{~s}^{-1}$ light intensity. Plants were treated with $\mathrm{ABA}(100 \mu \mathrm{M})$ or $\mathrm{NaCl}(200 \mathrm{mM})$ $[21,22]$. Plants treated without $\mathrm{ABA}$ and $\mathrm{NaCl}$ were used as control samples. Plants were sprayed with $100 \mu \mathrm{M}$ MeJA dissolved in $0.004 \%$ ethanol and then covered with a plastic bag. Plants sprayed with $0.004 \%$ ethanol were used as control samples. Stem tissues were harvested 1, 6, 12, 24, and $48 \mathrm{~h}$ after treatments. For drought treatment, watering was stopped for 4, 7, 10, and 14 days. For control samples, plants were grown in normal growth conditions with watering once in every 3 days. The harvested samples were frozen in liquid nitrogen and stored at $-80^{\circ} \mathrm{C}$.

2.3. RNA Isolation, Cloning, and QPCR Analysis. Total RNA was isolated from kenaf tissues as previously described [23]. Complementary DNA (cDNA) was synthesized using a Superscript III First-Strand Synthesis Kit (Invitrogen, Carlsbad, CA, USA). Degenerate primers were used to synthesize F5H fragment (forward primer, $5^{\prime}$-TT(T/C)TGG(C/A)G(T/G/C/A)CAGATG; reverse primer, $5^{\prime}$-TC(G/A)CT(C/T)G$\left.\mathrm{G}(\mathrm{C} / \mathrm{T}) \mathrm{TTCAT}-3^{\prime}\right)$. The degenerate primers were designed based on the conserved F5H sequences of Arabidopsis thaliana (AF068574), Brassica napus (DQ679758), Populus trichocarpa (AJ010324), Broussonetia papyrifera (AY850934), Eucalyptus globulus (FJ969838), and Camptotheca acumina (AY621153). The amplified product was cloned into the pGEM-T Easy Vector for sequencing (Promega, Madison, WI, USA). Both $5^{\prime}$ and $3^{\prime}$ RACE kits were used to clone a full length of $\mathrm{F} 5 \mathrm{H}$ ortholog following the manufacturer's instructions (Invitrogen). QPCR was performed as previously described [24] using the Mx3000P QPCR System (Agilent, Santa Clara, CA, USA) with SYBR Green QPCR Master Mix (LPS Solution, Daejeon, Korea). F5H primers used for QPCR were as follows: forward primer, $5^{\prime}$-CTCATTTGCTCCACAGTTTCACT- $3^{\prime}$; reverse primer, $5^{\prime}$-TCTATTTCCCTGCAGAGTAGTGTTG-3'. ACTIN gene (DQ866836) was used as an expression control: forward primer, $5^{\prime}$-ATGGACAAGTCATTACTATTGGAGC- $3^{\prime}$; reverse primer, $5^{\prime}$ AGTGATTTCCTTGCTCATACGGT-3'.

2.4. Data Analyses. The following programs were used to design primers and analyze DNA and protein sequences: NCBI Blast (http://blast.ncbi.nlm.nih.gov/), Biology WorkBench (http://workbench.sdsc.edu/), ExPASy Proteomics Server (http://web.expasy.org/compute_pi/) 
SignalP 4.0 (http://www.cbs.dtu.dk/services/SignalP/), and TargetP V1.1 (http://www.cbs.dtu.dk/services/TargetP/). A phylogenetic tree was constructed from the amino acid sequences by the neighbor joining method using Mega5 (http://www.megasoftware.net/). Duncan's multiple range test was applied to analyze the statistical significance of the differences among means at a significance of $P \leq 0.05$ using SASS (SASS Inc., Cary, NC, USA).

\section{Results}

3.1. Cloning of a Full-Length F5H Ortholog in Kenaf. The full length of kenaf $\mathrm{F5H}$ ortholog was cloned using degenerate primers and rapid amplification of cDNA ends (RACE) method. Kenaf F5H ortholog (GenBank Accession number JX524278) consists of a 1,557-bp open reading frame (ORF) that encodes 518 amino acids (Figure 1). The predicted molecular weight of the deduced protein was $58.62 \mathrm{kDa}$ with an isoelectric point $(\mathrm{p} I)$ of 5.84 as calculated by the ExPASy Proteomic Server. BlastP analysis revealed that the deduced amino acid sequence of kenaf F5H ortholog had high identities with other $\mathrm{F} 5 \mathrm{H}$ sequences (Figure 2). The deduced kenaf F5H ortholog shared 78, 78, 77, 77, and 77\% identities with $\mathrm{F} 5 \mathrm{H}$ sequences from Camptotheca acuminate (AAT39511), Populus trichocarpa (CAB65335), Eucalyptus globulus (ACU45738), Arabidopsis thaliana (CAC26936), and Arabidopsis lyrata (XP002867029), respectively (Figures 2 and 3). SignalP 4.0 and TargetP V1.1 analyses showed that no signal peptide was detected for subcellular localization in kenaf $\mathrm{F} 5 \mathrm{H}$ ortholog, which implies cytoplasmic localization. Motif Finder and PROSITE analyses suggested that kenaf F5H ortholog may contain a cytochrome P450 cysteine heme-iron ligand signature (FGSGRRSCPG, amino acid position 448-457; Figures 1 and 2), which exactly matched with the previously reported heme-binding ligand in Arabidopsis [25]. A phylogenetic tree was constructed from 10 F5H amino acid sequences using Mega 5 program (Figure 3). The phylogenetic tree showed that kenaf $\mathrm{F5H}$ ortholog had the closest relationship with Populus trichocarpa (CAB65335) and was grouped into a subcluster of 4 proteins: $P$. trichocarpa, Camptotheca acuminate (AAT39511), and Solanum lycopersicum $\times$ Solanum peruvianum (AAD37433). Cumulatively, all these results emphatically suggest that kenaf $\mathrm{F} 5 \mathrm{H}$ ortholog is a F5H enzyme. Therefore, kenaf $\mathrm{F} 5 \mathrm{H}$ ortholog was designated as $\mathrm{HcF} 5 \mathrm{H}$.

3.2. Expression of HcF5H Ortholog in Tissues. The expression patterns of $\mathrm{HcF} 5 \mathrm{H}$ transcript were analyzed in various tissues and organs including roots, stems, leaves, petioles, and flowers using QPCR. HcF5H transcript was found to be ubiquitous in all the tested samples (Figure 4(a)). A high level of $\mathrm{HcF} 5 \mathrm{H}$ transcript expression was observed in root, stem, and petiole tissues of 16-week-old kenaf plants. $\mathrm{HcF} 5 \mathrm{H}$ was highly expressed in young stems (6 week old, $4.54 \%$ relative ACTIN; Figure $4(\mathrm{~b})$ ) and immature flowers $(5.61 \%$ relative $A C T I N$; Figure $4(\mathrm{c})$ ), while the transcript level was not significantly induced during leaf development (Figure 4(d)). During stem development, $\mathrm{HcF} 5 \mathrm{H}$ transcript showed a significant increase at 6 weeks and then sharply decreased for up to 20 weeks. During flower development, the highest transcript level of $\mathrm{HcF} 5 \mathrm{H}$ was observed in immature flowers, while low level of the transcript was found in young and mature flowers. The transcript values during developmental stages in all tissues were significant $(P \leq 0.05)$, except for the transcripts in leaf development $(P>0.05)$.

3.3. Expression of HcF5H Ortholog in Response to Various Abiotic Stresses. HcF5H expression patterns were analyzed using 3-week-old stem tissues in their response to various abiotic stresses ( $\mathrm{NaCl}$, wounding, cold, ABA, MeJA, and drought) using QPCR. HcF5H transcript was induced by all treatments with the highest responses to $\mathrm{NaCl}$ and wounding treatments (Figure 5). The highest induction of $\mathrm{HcF} 5 \mathrm{H}$ was observed at $24-48 \mathrm{~h}$ after $\mathrm{NaCl}$ treatment. In wounding treatment, a biphasic expression was observed. $\mathrm{HcF} 5 \mathrm{H}$ was induced at $6 \mathrm{~h}$ after the treatment, declining marginally by $12 \mathrm{~h}$. The secondary induction was observed at $24 \mathrm{~h}$ after treatment, which was the highest in wounding treatment. The transcript was sharply downregulated later on. Biphasic expression was also observed in cold treatment, in which $\mathrm{HcF} 5 \mathrm{H}$ transcript was upregulated at $6 \mathrm{~h}$ after treatment and then sharply downregulated at $12 \mathrm{~h}$. The secondary induction was observed at $24 \mathrm{~h}$, when the highest transcript level was occurred. When kenaf was treated with ABA and MeJA, $\mathrm{HcF} 5 \mathrm{H}$ transcript reached its maximum level at $24 \mathrm{~h}$ after treatment. In ABA treatment, the transcript level increased up to $24 \mathrm{~h}$ after treatment and showed a decrease at $48 \mathrm{~h}$. In the case of MeJA, the transcript level was sharply increased at 12-24 h after treatment and then decreased at $48 \mathrm{~h}$. $\mathrm{HcF} 5 \mathrm{H}$ transcript level was maximum 7 days after watering was stopped and then dramatically decreased. All transcript values in response to various abiotic stresses were statistically significant based on Duncan's multiple range test $(P \leq 0.05)$.

\section{Discussion}

4.1. Characteristics of $\mathrm{HcF} 5 \mathrm{H}$. F5H enzyme is a cytochrome P450-dependent monooxygenase (P450s) that catalyzes the 5-hydroxylation of coniferaldehyde and/or coniferyl alcohol in the phenylpropanoid pathway [15]. P450s are a large group of heme-containing enzymes that generally catalyze $\mathrm{NADPH}$ - and $\mathrm{O}_{2}$-dependent hydroxylation reactions. In plants, two P450s catalyze reactions of the general phenylpropanoid pathway: cinnamate 4-hydroxylase $(\mathrm{C} 4 \mathrm{H})$ and ferulate 5-hydroxylase ( $\mathrm{F} 5 \mathrm{H})$. While $\mathrm{C} 4 \mathrm{H}$ belongs to $\mathrm{P} 450$ CYP73 family, F5H is a member of the CYP84 family of P450s [25]. Arabidopsis F5H was first defined as CYP84 and two F5H homologs (AtF5H1 and AtF5H2) were identified in the Arabidopsis genome [25]. AtF5H1 is now well characterized in many plants including Arabidopsis, Liquidambar styraciflua, and Brassica napus [25-27]. AtF5H2 is a more divergent member of the CYP84 family, and no genes that closely resemble AtF5H2 are found in other plants [28]. Three $\mathrm{F} 5 \mathrm{H}$ homologs were identified in Brassica napus (BnF5H1, $\mathrm{BnF} 5 \mathrm{H} 2$, and $\mathrm{BnF} 5 \mathrm{H} 3$ ) [27]. BnF5H1 and $\mathrm{BnF} 5 \mathrm{H} 2$ are very similar to each other $(98 \%$ identity at nucleotide sequence 


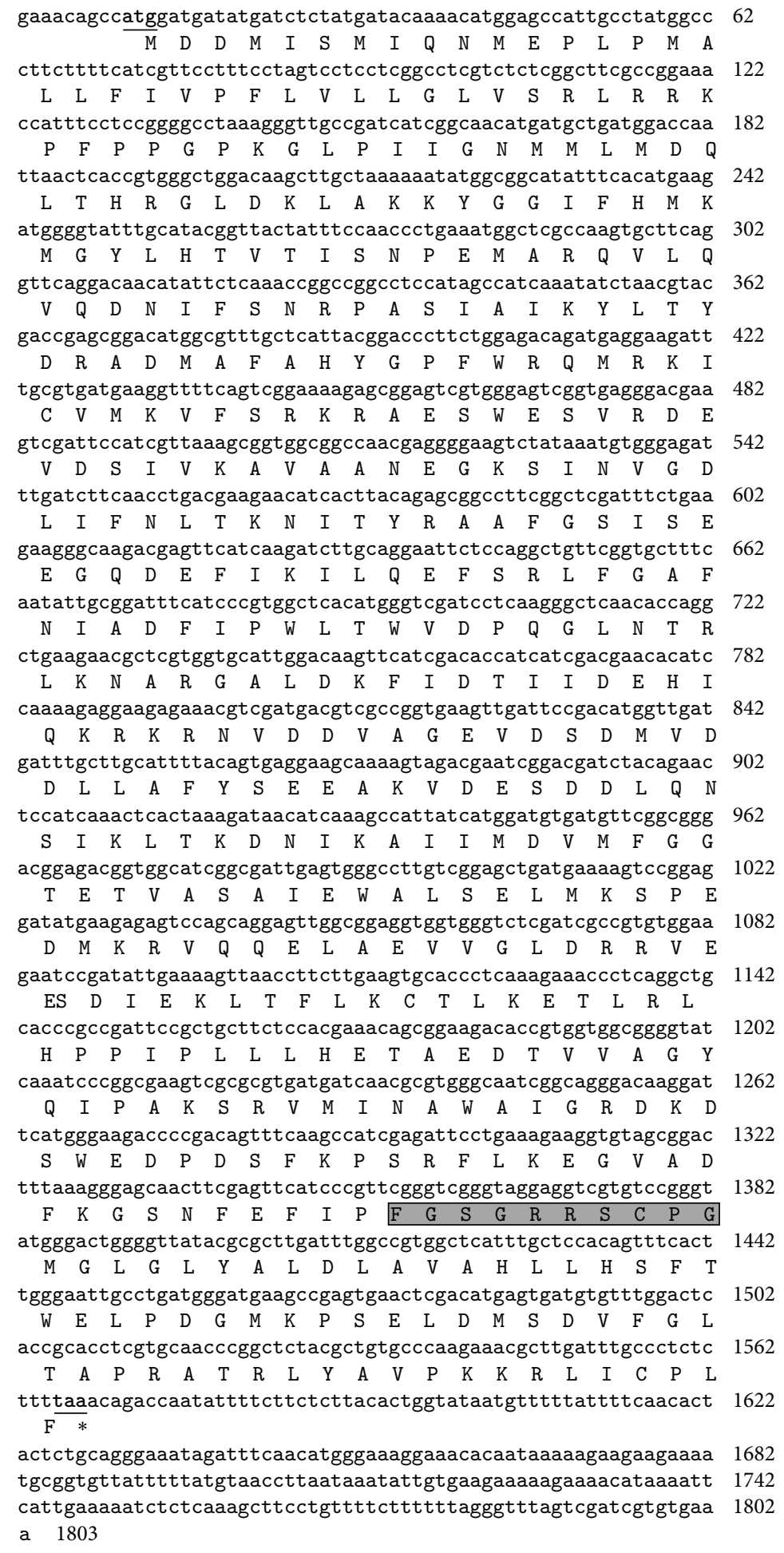

FIGURE 1: The cDNA and deduced amino acid sequences of F5H ortholog from kenaf. The start codon (atg) and stop codon (taa) are underlined and in bold. The gray box indicates the heme-binding ligand (FGSGRRCPG).

and $99 \%$ identity at amino acid sequence) and show high identity with AtF5Hs (90\% identity at amino acid sequence and $93 \%$ identity at amino acid sequence). Therefore, BnF5H1 and $\mathrm{BnF} 5 \mathrm{H} 2$ are thought to belong to one group. $\mathrm{BnF} 5 \mathrm{H} 3$ also shows the similar level of identity to the corresponding portion but lacks a codon for Proline at position 39, which is present in other F5H genes [27]. These two groups of BnF5H therefore must have been formed before the divergence. Also, the divergence between either $\mathrm{BnF} 5 \mathrm{H} 1$ or $\mathrm{BnF} 5 \mathrm{H} 2$ and $\mathrm{BnF} 5 \mathrm{H} 3$ suggests that the duplication may have occurred very 


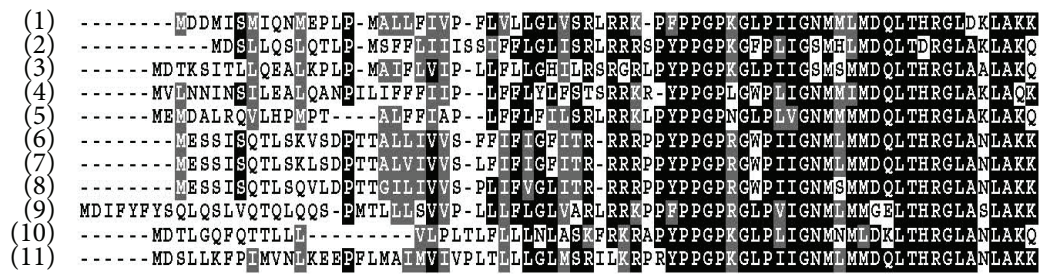

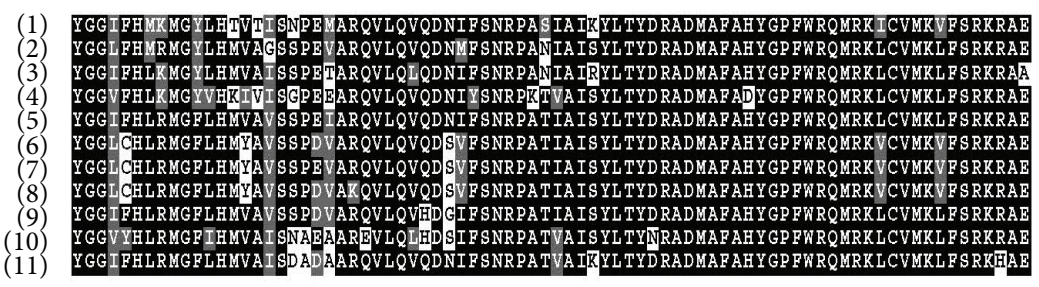

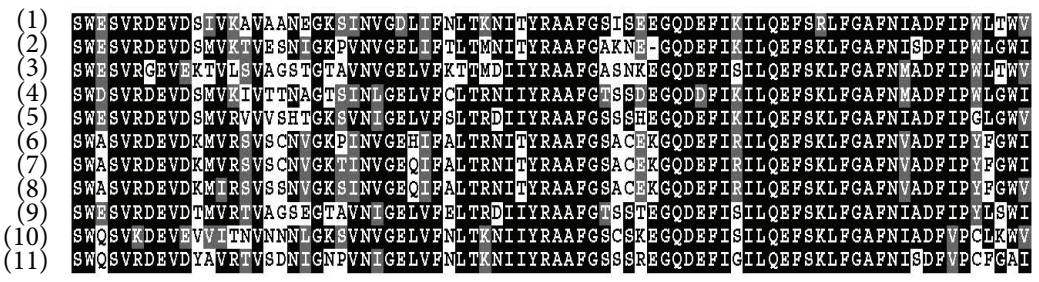

(11) DOSVAD

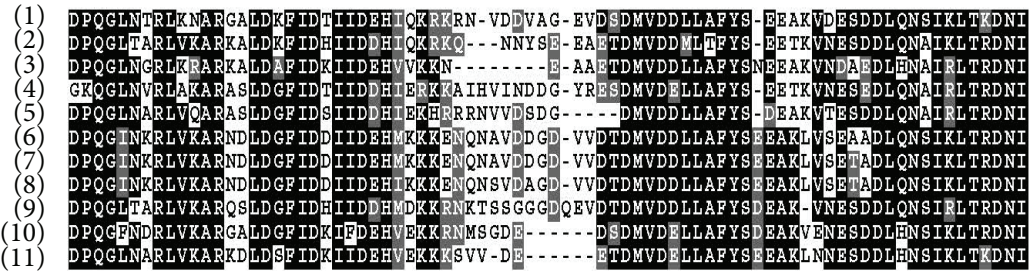

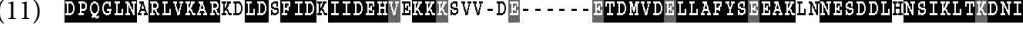

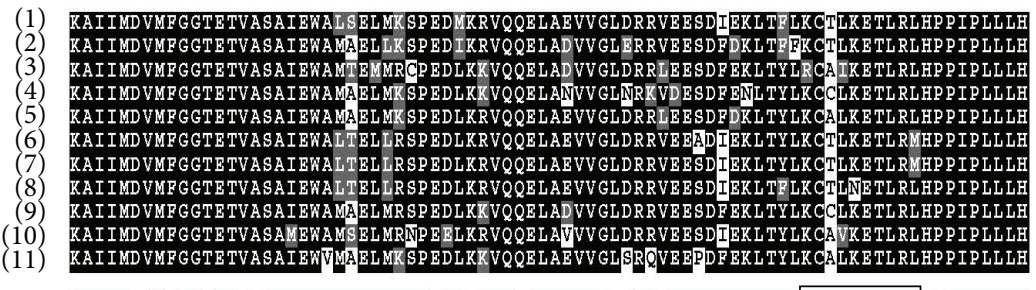

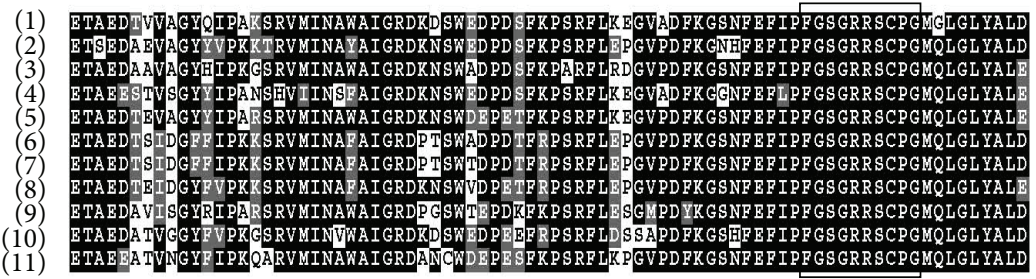

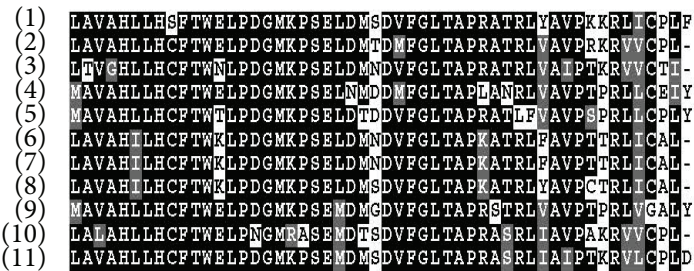

FIGURE 2: Multiple alignment of F5H sequences. ClustalW and BOXSHADE programs in Biology WorkBench were used to align the sequences. The amino acid residues shaded in black indicate amino acids that are identical with other F5H sequences. The heme-binding ligand (FGSGRRCPG) is boxed. The following F5H sequences were used: (1) Hibiscus cannabinus (JX524278), (2) Populus trichocarpa (CAB65335), (3) Broussonetia papyrifera (AAW50817), (4) Solanum lycopersicum $\times$ Solanum peruvianum (AAD37433), (5) Camptotheca acuminata (AAT39511), (6) Arabidopsis lyrata (XP002867029), (7) Arabidopsis thaliana (CAC26936), (8) Brassica napus (ABG73616), (9) Eucalyptus globulus (ACU45738), (10) Medicago truncatula (XP003629360), and (11) Medicago sativa (ABB02161). 


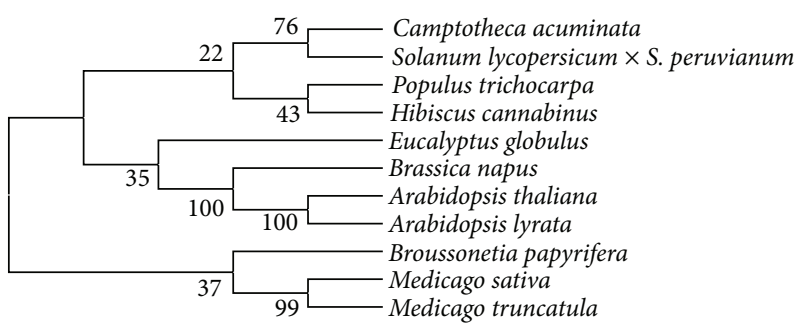

Figure 3: Phylogenic tree of F5H orthologs. The phylogenic tree was generated by the neighbor-joining method using ClustalW and Mega5 programs. The numbers at the nodes are bootstrap values from 1,000 replications. The following $\mathrm{F} 5 \mathrm{H}$ sequences were used: Hibiscus cannabinus (JX524278), Populus trichocarpa (CAB65335), Broussonetia papyrifera (AAW50817), Solanum lycopersicum $\times$ Solanum peruvianum (AAD37433), Camptotheca acuminata (AAT39511), Arabidopsis lyrata (XP002867029), Arabidopsis thaliana (CAC26936), Brassica napus (ABG73616), Eucalyptus globulus (ACU45738), Medicago truncatula (XP003629360), and Medicago sativa (ABB02161).

early in the lineage of the Brassica spp., whose ancestor has not been identified yet [29]. Only one putative $\mathrm{HcF} 5 \mathrm{H}$ gene was isolated in this study, but we suspect there might be more than one in kenaf. The deduced amino acid sequence of $\mathrm{HcF} 5 \mathrm{H}$ showed $74-78 \%$ identity with $\mathrm{F} 5 \mathrm{H}$ sequences of other plants (Figure 2). Phylogenic tree showed that $\mathrm{HcF} 5 \mathrm{H}$ shared amino acid sequence identity with other plant F5Hs (Figure 3). HcF5H may not contain a significant signal peptide, and so it is thought to be a cytoplasmic protein. In previous studies, however, AtF5H1 and AtF5H2 were found to contain fully conserved membrane anchor regions, and AtF5H2 was expected to have an ER-targeting peptide [28]. In our study, we identified that $\mathrm{HcF} 5 \mathrm{H}$ contains a cytochrome P450 cysteine heme-iron ligand signature (FGSGRRSCPG), which is homologous with the previously reported hemebinding domain that is well conserved in the CYPs of higher plants [30]. In addition, alignment of seven proteins of the CYP73 gene family showed similar results with the previous study [31]. Therefore, we conclude that $\mathrm{HcF} 5 \mathrm{H}$ may function as an $\mathrm{F} 5 \mathrm{H}$ enzyme.

\subsection{Significant Difference in HcF5H Expression in Different} Tissues and Developmental Stages. QPCR analysis revealed that $\mathrm{HcF} 5 \mathrm{H}$ was expressed in all tissues tested (Figure 4(a)). $\mathrm{HcF} 5 \mathrm{H}$ was not regulated during leaf development (Figure $4(\mathrm{~b}))$. The highest expression of $\mathrm{HcF} 5 \mathrm{H}$ was detected in immature flowers and young stems (Figures 4(c) and 4(d)). These results resemble the expression profile of AtF5H in Arabidopsis [28]. In Arabidopsis, both AtF5H1 and AtF5H2 were present in all tissues, with stem tissues expressing them at a high level. Moreover, AtF5H2 had the highest expression in the early stage of stem development. Most abundant transcript level of $\mathrm{BnF} 5 \mathrm{H}$ was also detected in the stem tissues of $B$. napus [27]. In kenaf, the highest expression level of $\mathrm{HcF} 5 \mathrm{H}$ was detected in young stem during stem development. The F5H-deficient mutant (fahl) accumulated only guaiacyl lignin, while $\mathrm{F} 5 \mathrm{H}$-overexpressing transgenic plant produced lignin with mostly syringyl propane units [20]. These results imply that F5H expression is essential for S lignin synthesis during stem development. In contrast to the previous studies, $\mathrm{HcF} 5 \mathrm{H}$ showed the highest expression level in immature flower tissues in our study. In flowers and seeds, $\mathrm{F} 5 \mathrm{H}$ is required for the production of sinapate esters, which are intermediates of syringyl lignin biosynthesis in higher plants, and some of them serve as precursors for important secondary metabolites [32]. For example, phenylpropanoidderived compounds such as sinapate and flavonoids were detected at high levels in Arabidopsis flowers [33]. In addition, disruption of $A t F 5 H$ led to a limited production of lignin, which resulted in a dwarf floral architecture in the $f 5 \mathrm{~h}$ mutant [34]. Therefore, $\mathrm{F} 5 \mathrm{H}$ is an important enzyme in flower development. In this study, $\mathrm{HcF} 5 \mathrm{H}$ expression was found to be significantly induced during flower development, reaching its maximum level in the immature flower. Overexpression of AtF5H in AtCOMT-deficient Arabidopsis caused the accumulation of $5 \mathrm{H}$ monomers [35]. These $5 \mathrm{H}$ monomers were either directly or indirectly detrimental to pollen wallforming sporopollenin biosynthesis, which is thought to protect pollens from UV radiation and desiccation. The overexpression of $\mathrm{HcF} 5 \mathrm{H}$ during flower development could be explained by the pollen wall formation. Overall, expression patterns of $\mathrm{HcF} 5 \mathrm{H}$ strongly point toward the possibility that this putative enzyme may function as $\mathrm{F} 5 \mathrm{H}$ in kenaf.

\subsection{Significant Induction of HcF5H in Response to Various} Abiotic Stresses. Plants are subjected to various stress conditions during their life time. They have a generic signal transduction pathway that starts with signal perception, followed by the generation of second messengers such as calcium, reactive oxygen species (ROS), and inositol phosphates [36]. These biotic and abiotic stresses can turn on a plant's defense mechanisms, which include the production of various defensive enzymes and proteins as well as cell wall reinforcement through lignin deposition [23, 37-39]. Lignin induction has been correlated with cold, drought, or light stresses as well as mechanical injuries in plants [23]. Although lignin biosynthesis itself is well characterized, the mechanism regulating ectopic deposition of lignin in response to environmental stimuli is not well understood. Environmental stresses can activate the synthesis of phytohormones in plants $[40,41]$. These phytohormones can produce the initial signals for the gene regulation in lignin biosynthesis and others. The initial signals subsequently produce a second-round signaling pathway. In previous studies, we showed that kenaf genes involved in lignin biosynthesis were controlled by various environmental stresses and phytohormones [42-46]. However, this is the first report that showed the upregulation of $\mathrm{HcF} 5 \mathrm{H}$ as a result of various abiotic stresses in kenaf. $\mathrm{HcF} 5 \mathrm{H}$ is found to be induced in response to treatments that include wounding, cold, drought, and additions of $\mathrm{NaCl}$, $\mathrm{ABA}$, and MeJA (Figure 5).

$\mathrm{NaCl}$. Soil salinity poses a severe environmental restriction limiting the availability of land for sustainable agriculture [47]. Many scientists have identified the genes that cause 


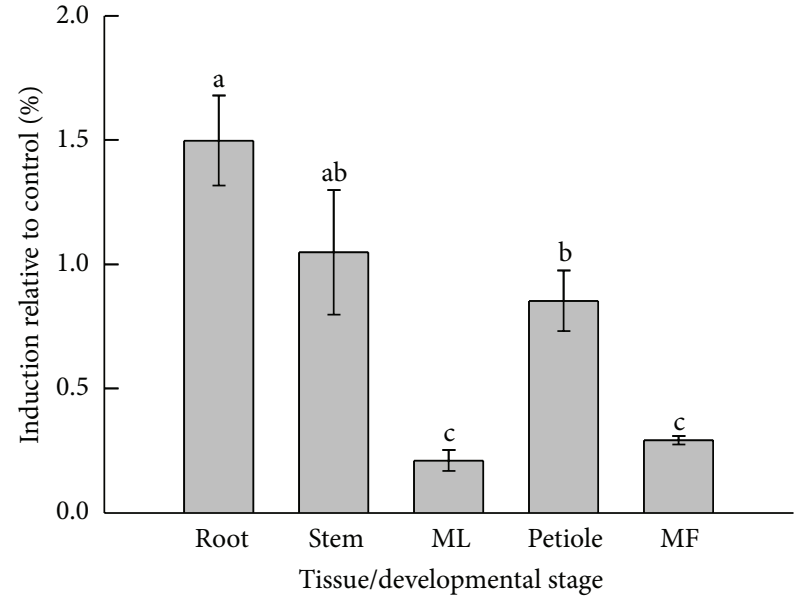

(a)

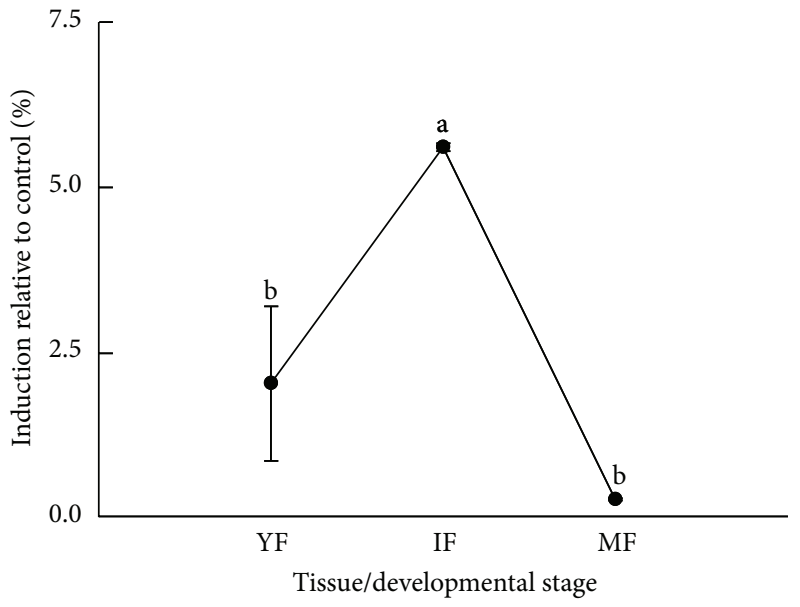

(c)

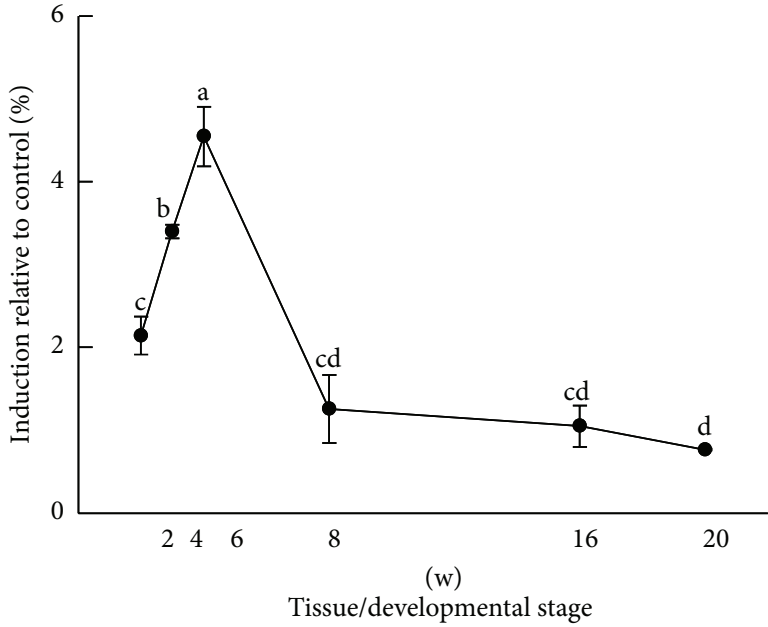

(b)

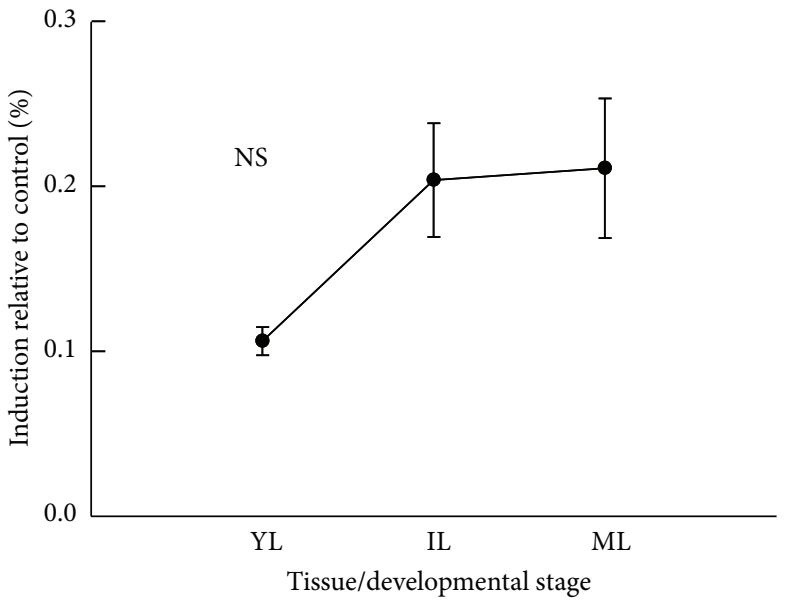

(d)

FIGURE 4: Expression patterns of $\mathrm{HcF5H}$ ortholog during developmental stages in various tissues. $H c F 5 H$ ortholog was measured using QPCR, and the transcript level was calculated with respect to ACTIN level. The percent induction relative to control was calculated after deduction of the control transcript level. (a) $H c F 5 H$ transcript level in various tissues and organs from 16 -week-old plants, (b) $H c F 5 H$ transcript level during stem development $(2,4,6,8,16$, and 20 weeks after sowing), (c) $H c F 5 H$ transcript level during flower development (YF: young flower; IF: immature flower; MF: mature flower), and (d) HcF5H transcript level during leaf development (YL: young leaf; IL: immature leaf; ML: mature leaf). The vertical bars indicate means \pm standard error of three biological replications. The letters on top of each point indicate significant differences between the mean values $(P \leq 0.05)$. NS: not significant; w: week.

salt tolerance, so that the effects of salinity in agriculture can be overcome. According to previous reports, increased lignification or altered monolignol composition in plant cell walls provides an effective way to overcome salinity stress [48]. In this study, $\mathrm{HcF5H}$ was highly induced by $\mathrm{NaCl}$ (Figure 5). Similar result was reported in Brassica juncea [49]. Moreover, $\mathrm{NaCl}$ treatment also induced the genes encoding $S$-adenosyl-1-methionine synthase (SAMS) in tomato, $O$ methyltransferase (COMT) in Tamarix hispida, and phenylalanine ammonia-lyase (PAL), $\rho$-coumarate 3-hydroxylase $(\mathrm{C} 3 \mathrm{H})$, and caffeoyl-coenzyme A 3-O-methyltransferase (CCoAMT) in kenaf $[42,44,45,50,51]$.

Wounding. Wounding has proved to be one of the most effective ways by which control of phenylpropanoid biosynthesis can be understood $[23,52,53]$. For example, wounding induces the genes involved in lignin biosynthesis, such as PAL (phenylalanine ammonia-lyase), C4H (cinnamate 4hydroxylase), F5H, CAD (cinnamyl alcohol dehydrogenase), CCR (cinnamoyl-CoA reductase), and 4CL (4-coumarateCoA ligase), which caused accumulation of lignin compounds surrounding the wounding sites $[23,52,53]$. Wounding also induced the synthesis of lignin precursors and ferulate esters in Solanum tuberosum [54]. QPCR analysis suggests that $\mathrm{HcF} 5 \mathrm{H}$ is highly induced by wounding (Figure 5). These results point to the fact that plants enhance lignin production in order to protect them from wounding through the regulation of the genes involved in lignin biosynthesis such as $F 5 H$.

Cold. Low temperature causes an alteration in plant lignin contents [23]. The adaptation of plants to low temperature 

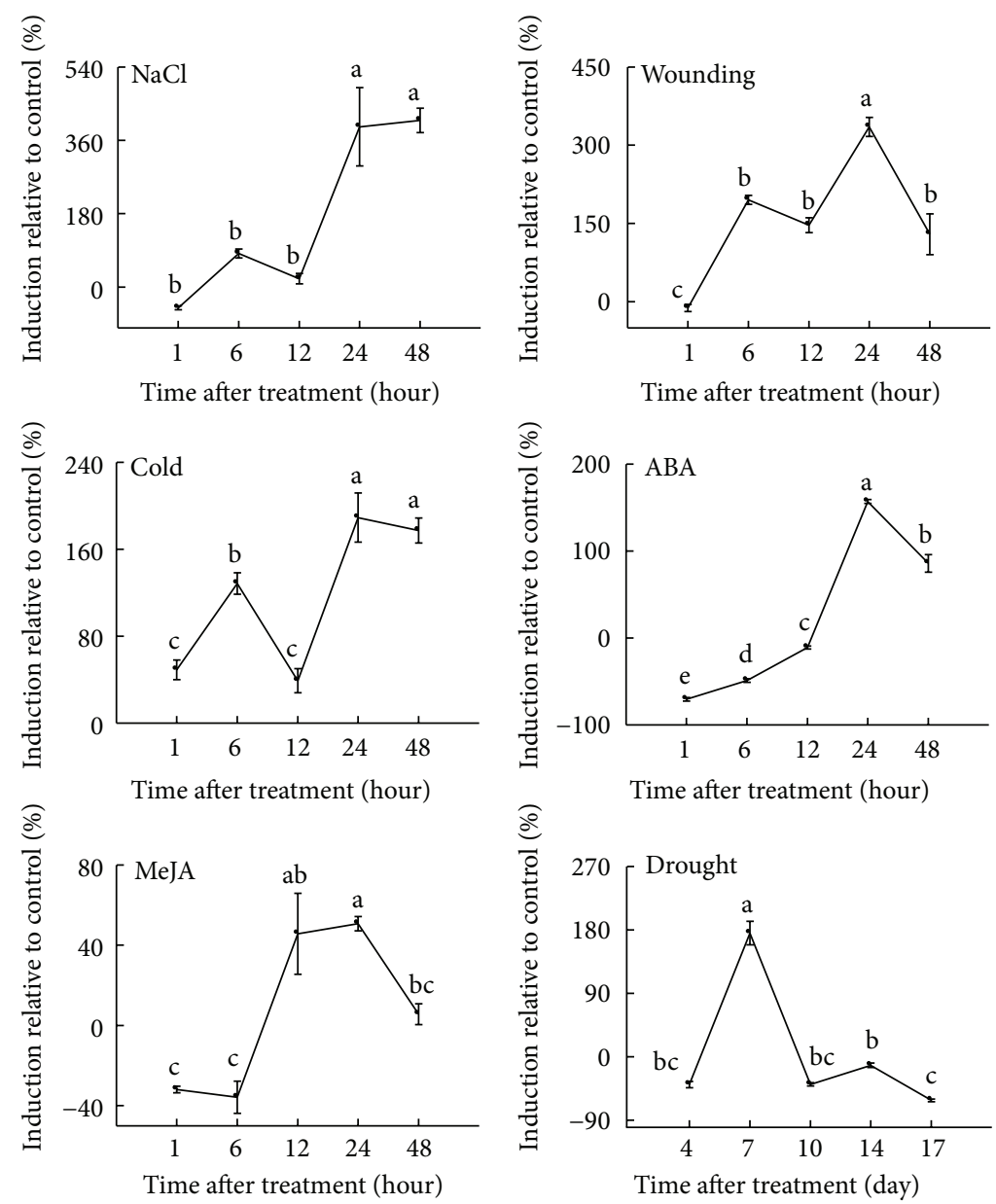

FIGURE 5: Expression patterns of $\mathrm{HcF} 5 \mathrm{H}$ ortholog in response to various abiotic stresses. Abiotic stresses were applied to 3-week-old plants, and stem tissues were harvested for QPCR analysis. HcF5H ortholog was measured using QPCR, and the transcript level was calculated with respect to ACTIN level. The percent induction relative to control was calculated after deduction of the control transcript level. The vertical bars indicate means \pm standard error of three biological replications. The letters on top of each point indicate significant differences between the mean values $(P \leq 0.05)$.

is thought to involve a genetic response controlling the physical and biochemical changes. It was reported that poplar seedlings grown at $10^{\circ} \mathrm{C}$ showed an increase in lignin content [55]. Cold treatment induced the accumulation of phenylpropanoid lignin precursors such as $\rho$-coumaric acid, ferulic acid, and synaptic acid in Brassica napus [56]. A total 3,379 genes showed altered expression patterns during cold acclimation in Arabidopsis [57]. As a key enzyme in lignin synthesis, $\mathrm{F} 5 \mathrm{H}$ induction by cold might lead to lignification in kenaf stem tissues. It has been reported that cold treatment can upregulate the genes involved in lignin synthesis such as PAL, CCOAOMT, C3H, HCT, and COMT1 in kenaf stem tissues [42-46].

$A B A$. The universal stress hormone $\mathrm{ABA}$ is substantially induced during a plant's response to abiotic stress [58]. When the salt stress signal is received by plants, ABA synthesis is induced, which triggers other signaling processes such as the accumulation of calcium ions [59]. ABA is an important phytohormone and plays a critical role in response to stresses including drought, cold, and osmotic stress [60, 61]. Studies suggest that two types of $\mathrm{ABA}$ signal transduction pathways are present in plants: one is ABA-independent, and the other is ABA-dependent [60]. The genes involved in ABA biosynthesis were induced by drought and cold treatments, and they were not responsive to exogenous ABA treatment [60]. When detached leaves were treated with $\mathrm{ABA}, \mathrm{F} 5 \mathrm{H}$ was found to be induced in Camptotheca acuminata [62], suggesting that F5H might belong to the ABA-dependent pathway. Similar response pattern was observed when $\mathrm{HcF} 5 \mathrm{H}$ was treated with $\mathrm{ABA}$, indicating that $\mathrm{HcF} 5 \mathrm{H}$ can be categorized into an ABA-dependent pathway. Similar induction patterns were observed for treatments with $\mathrm{ABA}$ and $\mathrm{NaCl}$.

MeJA. Exogenous application of MeJA caused the accumulation of lignin, phenolic compounds, and defense enzymes in eggplant roots [63]. Jasmonic acid (JA) or its methyl ester jasmonate acts as an important regulator of responses to wounding and environmental stresses [64]. CaF5H transcript was induced by MeJA treatment in Camptotheca acuminate 
[62]. In our study, we found the upregulation of $\mathrm{F} 5 \mathrm{H}$ by MeJA in kenaf. This result strongly suggests that MeJA-dependent pathway regulates wound-induced $\mathrm{F} 5 \mathrm{H}$ activation similar to other $\mathrm{F} 5 \mathrm{H}$ orthologs. However, MeJA treatment only weakly induced $\mathrm{HcF} 5 \mathrm{H}$ compared to other treatments. Similar result was observed in the expression of $\mathrm{CaF5H}$ [62]. It is thought that exogenous $\mathrm{MeJA}$ alone might not be effective in mediating the expression of $F 5 \mathrm{H}$. Other factors such as ABA and $\mathrm{H}_{2} \mathrm{O}_{2}$ are also required for stronger expression.

Drought. In this study, drought induced $\mathrm{HcF} 5 \mathrm{H}$ expression at early time point after watering was stopped (7 days). $\mathrm{HcF} 5 \mathrm{H}$ sharply dropped to initial levels later. The level of lignin deposition and gene expression may be dependent on plant tissues and drought period. In a previous study, there was a reduction in the amount of ferulic acid and an induction of $\rho$-coumaric and caffeic acids in maize xylem sap 12 days after watering was stopped [65]. Previous studies reported the induction of genes involved in lignin biosynthesis [23, 42-45]. During the drought period, plant cell wall becomes impermeable to water due to the accumulation of lignin, which causes the reduction in water transpiration [66]. Therefore, it is thought that lignification is one of the primary responses to drought stress.

In summary, a full length of the gene $F 5 H$ encoding ferulate 5-hydroxylase was cloned from kenaf (Hibiscus cannabinus L.). Transcriptional and phylogenetic analyses indicated that $\mathrm{HcF} 5 \mathrm{H}$ ortholog belonged to known $\mathrm{F} 5 \mathrm{H}$ genes of plants. On the transcript level, $\mathrm{HcF} 5 \mathrm{H}$ was regulated by the developmental stages in various tissues and in response to various abiotic stresses. These results suggest that $\mathrm{HcF} 5 \mathrm{H}$ may play important roles in kenaf plant for better adaptation to environmental stresses.

\section{Acknowledgment}

This work was supported by a Grant from the NextGeneration Biogreen 21 Program (PJ00806302), Rural Development Administration, Republic of Korea.

\section{References}

[1] J. Dempsey, Fiber Crops, The University Presses of Gainesville, Gainesville, Fla, USA, 1975.

[2] H. Pande and D. N. Roy, "Delignification kinetics of soda pulping of kenaf," Journal of Wood Chemistry and Technology, vol. 16, no. 3, pp. 311-325, 1996.

[3] A. Ahmed, G. Scott, M. Akhtar, and G. C. Myers, "Biokraft pulping of kenaf and its bleachability," in Proceedings of the North American Nonwood Fiber Symposium, pp. 231-238, Atlanta, Ga, USA, 1998.

[4] L. Francois, T. Donovan, and E. Maas, "Yield, vegetative growth, and fibre length of kenaf grown on saline soil," Agronomy Journal, vol. 84, pp. 592-598, 1992.

[5] T. B. T. Lam, K. Hori, and K. Iiyama, "Structural characteristics of cell walls of kenaf (Hibiscus cannabinus L.) and fixation of carbon dioxide," Journal of Wood Science, vol. 49, no. 3, pp. 255261, 2003.
[6] M. T. P. Nguyen, T. Araki, and F. Kubota, "Comparison of growth feature and drought tolerance between two high productive species, kenaf (Hibicus cannabinus, C3-plant) and napiergrass (Pennisetum purpureum, C4-plant)," Journal of the Faculty of Agriculture, Kyushu University, vol. 50, no. 2, pp. 521532, 2005.

[7] W. Boerjan, J. Ralph, and M. Baucher, "Lignin Biosynthesis," Annual Review of Plant Biology, vol. 54, pp. 519-546, 2003.

[8] R. Vanholme, B. Demedts, K. Morreel, J. Ralph, and W. Boerjan, "Lignin biosynthesis and structure," Plant Physiology, vol. 153, no. 3, pp. 895-905, 2010.

[9] G. Neutelings, "Lignin variability in plant cell walls: contribution of new models," Plant Science, vol. 181, no. 4, pp. 379-386, 2011.

[10] J.-K. Weng, X. Li, N. D. Bonawitz, and C. Chapple, "Emerging strategies of lignin engineering and degradation for cellulosic biofuel production," Current Opinion in Biotechnology, vol. 19, no. 2, pp. 166-172, 2008.

[11] M. B. Sticklen, "Plant genetic engineering for biofuel production: towards affordable cellulosic ethanol," Nature Reviews Genetics, vol. 9, no. 6, pp. 433-443, 2008.

[12] S. D. Mansfield, "Solutions for dissolution-engineeringcell walls for deconstruction," Current Opinion in Biotechnology, vol. 20, pp. 286-294, 2009.

[13] X. Li, J.-K. Weng, and C. Chapple, "Improvement of biomass through lignin modification," Plant Journal, vol. 54, no. 4, pp. 569-581, 2008.

[14] T. Vogt, "Phenylpropanoid biosynthesis," Molecular Plant, vol. 3, no. 1, pp. 2-20, 2010.

[15] M. Baucher, C. Halpin, M. Petit-Conil, and W. Boerjan, "Lignin: genetic engineering and impact on pulping," Critical Reviews in Biochemistry and Molecular Biology, vol. 38, no. 4, pp. 305-350, 2003.

[16] Z. Xu, D. Zhang, J. Hu et al., "Comparative genome analysis of lignin biosynthesis gene families across the plant kingdom," BMC Bioinformatics, vol. 10, no. 11, article 1471, p. S3, 2009.

[17] A. Gutiérrez, I. Rodríguez, and J. Del Río, "Chemical characterization of lignin and lipid fractions in kena fbast fibers used for manufacturing high-quality papers," Journal of Agricultural and Food Chemistry, vol. 52, pp. 4764-4773, 2004.

[18] G. Marques, J. Rencoret, A. Gutiérrez, and J. del Río, "Evaluation of the chemical composition of different non-woody plant fibers used for pulp and paper manufacturing," The Open Agriculture Journal, vol. 4, pp. 93-101, 2010.

[19] S. K. Huntley, D. Ellis, M. Gilbert, C. Chapple, and S. D. Mansfield, "Significant increases in pulping efficiency in $\mathrm{C} 4 \mathrm{H}-f 5 h$ transformed poplars: improved chemical savings and reduced environmental toxins," Journal of Agricultural and Food Chemistry, vol. 51, no. 21, pp. 6178-6183, 2003.

[20] K. Meyer, A. M. Shirley, J. C. Cusumano, D. A. Bell-Lelong, and C. Chapple, "Lignin monomer composition is determined by the expression of a cytochrome P450-dependent monooxygenase in Arabidopsis," Proceedings of the National Academy of Sciences of the United States of America, vol. 95, no. 12, pp. 66196623, 1998.

[21] Q. Gao, Y. Liu, M. Wang et al., "Molecular cloning and characterization of an inducible RNA-dependent RNA polymerase gene, GhRdRP, from cotton (Gossypium hirsutum L.)," Molecular Biology Reports, vol. 36, no. 1, pp. 47-56, 2009.

[22] H. Zheng, S. Lin, Q. Zhang, Y. Lei, L. Hou, and Z. Zhang, "Functional identification and regulation of the PtDrl02 gene 
promoter from triploid white poplar," Plant Cell Reports, vol. 29, no. 5, pp. 449-460, 2010.

[23] J. C. M. S. Moura, C. A. V. Bonine, J. de Oliveira Fernandes Viana, M. C. Dornelas, and P. Mazzafera, "Abiotic and biotic stresses and changes in the lignin content and composition in plants," Journal of Integrative Plant Biology, vol. 52, no. 4, pp. 360-376, 2010.

[24] H. Bae, S.-H. Kim, M. S. Kim et al., "The drought response of Theobroma cacao (cacao) and the regulation of genes involved in polyamine biosynthesis by drought and other stresses," Plant Physiology and Biochemistry, vol. 46, no. 2, pp. 174-188, 2008.

[25] K. Meyer, J. C. Cusumano, C. Somerville, and C. C. S. Chapple, "Ferulate-5-hydroxylase from Arabidopsis thaliana defines a new family of cytochrome P450-dependent monooxygenases," Proceedings of the National Academy of Sciences of the United States of America, vol. 93, no. 14, pp. 6869-6874, 1996.

[26] K. Osakabe, C. C. Tsao, L. Li et al., "Coniferyl aldehyde 5hydroxylation and methylation direct syringyl lignin biosynthesis in angiosperms," Proceedings of the National Academy of Sciences of the United States of America, vol. 96, no. 16, pp. 89558960, 1999.

[27] R. B. Nair, R. W. Joy IV, E. Kurylo et al., "Identification of a CYP84 family of cytochrome P450-dependent monooxygenase genes in Brassica napus and perturbation of their expression for engineering sinapine reduction in the seeds," Plant Physiology, vol. 123, no. 4, pp. 1623-1634, 2000.

[28] J. Raes, A. Rohde, J. H. Christensen, Y. Van De Peer, and W. Boerjan, "Genome-wide characterization of the lignification toolbox in arabidopsis," Plant Physiology, vol. 133, no. 3, pp. 1051-1071, 2003.

[29] M. J. Truco, J. Hu, J. Sadowski, and C. F. Quiros, "Inter- and intra-genomic homology of the Brassica genomes: implications for their origin and evolution," Theoretical and Applied Genetics, vol. 93, no. 8, pp. 1225-1233, 1996.

[30] S. Lee, E. Lee, B. An et al., "Molecular cloning and characterization of cinnamate-4-hydroxylase gene from Rubus coreanus," The Open Plant Science Journal, vol. 2, pp. 31-36, 2008.

[31] A. Gravot, R. Larbat, A. Hehn et al., "Cinnamic acid 4hydroxylase mechanism-based inactivation by psoralen derivatives: cloning and characterization of a $\mathrm{C} 4 \mathrm{H}$ from a psoralen producing plant-Ruta graveolens-exhibiting low sensitivity to psoralen inactivation," Archives of Biochemistry and Biophysics, vol. 422, no. 1, pp. 71-80, 2004.

[32] M. Ruegger, K. Meyer, J. C. Cusumano, and C. Chapple, "Regulation of ferulate-5-hydroxylase expression in Arabidopsis in the context of sinapate ester biosynthesis," Plant Physiology, vol. 119, no. 1, pp. 101-110, 1999.

[33] C. Chapple, B. Shirley, M. Zook, R. Hammerschmidt, and S. Somerville, "Secondary metabolism in Arabidopsis," in Arabidopsis, E. M. Meyerowitz, Ed., pp. 989-1030, Cold Spring Harbor Laboratory Press, Cold Spring Harbor, NY, USA, 1994.

[34] J. Huang, V.-S. Bhinu, X. Li, Z. D. Bashi, R. Zhou, and A. Hannoufa, "Pleiotropic changes in Arabidopsis $f 5 h$ and sct mutants revealed by large-scale gene expression and metabolite analysis," Planta, vol. 230, no. 5, pp. 1057-1069, 2009.

[35] J.-K. Weng, H. Mo, and C. Chapple, "Over-expression of $f 5 h$ in COMT-deficient Arabidopsis leads to enrichment of an unusual lignin and disruption of pollen wall formation," Plant Journal, vol. 64, no. 6, pp. 898-911, 2010.

[36] G.-T. Huang, S.-L. Ma, L.-P. Bai et al., "Signal transduction during cold, salt, and drought stresses in plants," Molecular Biology Reports, vol. 39, no. 2, pp. 969-987, 2012.
[37] C. Hano, M. Addi, L. Bensaddek et al., "Differential accumulation of monolignol-derived compounds in elicited flax (Linum usitatissimum) cell suspension cultures," Planta, vol. 223, no. 5, pp. 975-989, 2006.

[38] S. Desender, D. Andrivon, and F. Val, "Activation of defence reactions in Solanaceae: where is the specificity?" Cellular Microbiology, vol. 9, no. 1, pp. 21-30, 2007.

[39] T. Hamann, M. Bennett, J. Mansfield, and C. Somerville, "Identification of cell-wall stress as a hexose-dependent and osmosensitive regulator of plant responses," Plant Journal, vol. 57, no. 6, pp. 1015-1026, 2009.

[40] S. Mahajan and N. Tuteja, "Cold, salinity and drought stresses: an overview," Archives of Biochemistry and Biophysics, vol. 444, no. 2, pp. 139-158, 2005.

[41] H.-B. Shao, Q.-J. Guo, L.-Y. Chu et al., "Understanding molecular mechanism of higher plant plasticity under abiotic stress," Colloids and Surfaces B, vol. 54, no. 1, pp. 37-45, 2007.

[42] B. Choi, S. Y. Kang, H. J. Bae, H. S. Lim, W. S. Bang, and H. Bae, "Transcriptional analys is of the $\rho$-coumarate 3 -hydroxylase $(\mathrm{C} 3 \mathrm{H})$ gene from Hibiscus cannabinus L. during developmental stages in various tissues and in response to abiotic stresses," Research Journal of BioTechnology, vol. 7, pp. 23-33, 2012.

[43] E. M. Chowdhury, B. Choi, S. U. Park, H. S. Lim, and H. Bae, "Transcriptional analysis of hydroxycinnamoyltransferase (HCT) in various tissues of Hibiscus cannabinusin response to abiotic stress conditions," Plant Omics Journal, vol. 5, pp. 305313, 2012.

[44] R. Ghosh, B. Choi, M. J. Jeong et al., "Comparative transcriptional analysis of caffeoyl-coenzyme A 3-O-methyltransferase from Hibiscus cannabinus L., during developmental stages in various tissues and stress regulation," Plant Omics Journal, vol. 5, pp. 184-193, 2012.

[45] M. J. Jeong, B. Choi, D. W. Bae et al., "Differential expression of kenaf phenylalanine ammonia-lyase (PAL) ortholog during developmental stages and in response to abiotic stresses," Plant Omics Journal, vol. 5, pp. 392-399, 2012.

[46] J. Kim, B. Choi, S. Natarajan, and H. Bae, "Expression analysis of kenafcinnamate 4-hydroxylase $(\mathrm{C} 4 \mathrm{H})$ ortholog during developmental and stress responses," Plant Omics Journal, vol. 6, pp. 65-72, 2013.

[47] FAO, "Land resources, management, planning and use," 2008, http://www.fao.org/ag/agl/agll/spush/.

[48] G. Y. S. Neves, R. Marchiosi, M. L. L. Ferrarese, R. C. SiqueiraSoares, and O. Ferrarese-Filho, "Root growth inhibition and lignification induced by salt stress in soybean," Journal of Agronomy and Crop Science, vol. 196, no. 6, pp. 467-473, 2010.

[49] A. K. Srivastava, N. K. Ramaswamy, P. Suprasanna, and S. F. D'Souza, "Genome-wide analysis of thiourea-modulated salinity stress-responsive transcripts in seeds of Brassica juncea: identification of signalling and effector components of stress tolerance," Annals of Botany, vol. 106, no. 5, pp. 663-674, 2010.

[50] I. Sánchez-Aguayo, J. M. Rodríguez-Galán, R. García, J. Torreblanca, and J. M. Pardo, "Salt stress enhances xylem development and expression of S-adenosyl-L-methionine synthase in lignifying tissues of tomato plants," Planta, vol. 220, no. 2, pp. 278-285, 2004.

[51] H. Li, Y. Wang, J. Jiang, G. Liu, C. Gao, and C. Yang, "Identification of genes responsive to salt stress on Tamarix hispida roots," Gene, vol. 433, no. 1-2, pp. 65-71, 2009.

[52] C. Delessert, L. W. Wilson, D. Van Der Straeten, E. S. Dennis, and R. Dolferus, "Spatial and temporal analysis of the local 
response to wounding in Arabidopsis leaves," Plant Molecular Biology, vol. 55, no. 2, pp. 165-181, 2004.

[53] B. M. Soltani, J. Ehlting, B. Hamberger, and C. J. Douglas, "Multiple cis-regulatory elements regulate distinct and complex patterns of developmental and wound-induced expression of Arabidopsis thaliana 4CL gene family members," Planta, vol. 224, no. 5, pp. 1226-1238, 2006.

[54] M. A. Bernards and N. G. Lewis, "Alkyl ferulates in wound healing potato tubers," Phytochemistry, vol. 31, no. 10, pp. 3409$3412,1992$.

[55] J. F. Hausman, D. Evers, H. Thiellement, and L. Jouve, "Compared responses of poplar cuttings and in vitro raised shoots to short-term chilling treatments," Plant Cell Reports, vol. 19, no. 10, pp. 954-960, 2000.

[56] D. Solecka, A.-M. Boudet, and A. Kacperska, "Phenylpropanoid and anthocyanin changes in low-temperature treated winter oilseed rape leaves," Plant Physiology and Biochemistry, vol. 37, no. 6, pp. 491-496, 1999.

[57] M. A. Hannah, A. G. Heyer, and D. K. Hincha, "A global survey of gene regulation during cold acclimation in Arabidopsis thaliana," PLoS Genetics, vol. 1, no. 2, p. e26, 2005.

[58] N. Sreenivasulu, V. T. Harshavardhan, G. Govind, C. Seiler, and A. Kohli, "Contrapuntal role of ABA: does it mediate stress tolerance or plant growth retardation under long-term drought stress?" Gene, vol. 506, pp. 265-273, 2012.

[59] G. Jakab, J. Ton, V. Flors, L. Zimmerli, J.-P. Métraux, and B. Mauch-Mani, "Enhancing Arabidopsis salt and drought stress tolerance by chemical priming for its abscisic acid responses," Plant Physiology, vol. 139, no. 1, pp. 267-274, 2005.

[60] J.-K. Zhu, "Salt and drought stress signal transduction in plants," Annual Review of Plant Biology, vol. 53, pp. 247-273, 2002.

[61] N. Tuteja, "Abscisic acid and abiotic stress signaling," Plant Signaling and Behavior, vol. 2, no. 3, pp. 135-138, 2007.

[62] Y. J. Kim, D. G. Kim, S. H. Lee, and I. Lee, "Wound-induced expression of the ferulate 5-hydroxylase gene in Camptotheca acuminate," Biochimica et Biophysica Acta, vol. 1760, pp. 182190, 2005.

[63] S. Mandal, "Induction of phenolics, lignin and key defense enzymes in eggplant (Solanum melongena L.) roots in response to elicitors," African Journal of Biotechnology, vol. 9, no. 47, pp. 8038-8047, 2010.

[64] S. Fonseca, J. M. Chico, and R. Solano, “The jasmonate pathway: the ligand, the receptor and the core signalling module," Current Opinion in Plant Biology, vol. 12, no. 5, pp. 539-547, 2009.

[65] S. Alvarez, E. L. Marsh, S. G. Schroeder, and D. P. Schachtman, "Metabolomic and proteomic changes in the xylem sap of maize under drought," Plant, Cell and Environment, vol. 31, no. 3, pp. 325-340, 2008.

[66] B. Monties and K. Fukushima, "Occurence, function and biosynthesis of lignins," in Lignin, Humic Substances and Coal, A. Steinbüchel, M. Hofrichter, and A. Steinbüchel, Eds., vol. 1 of Biopolymers, pp. 1-64, Wiley-VCH, Weinheim, Germany, 2001. 

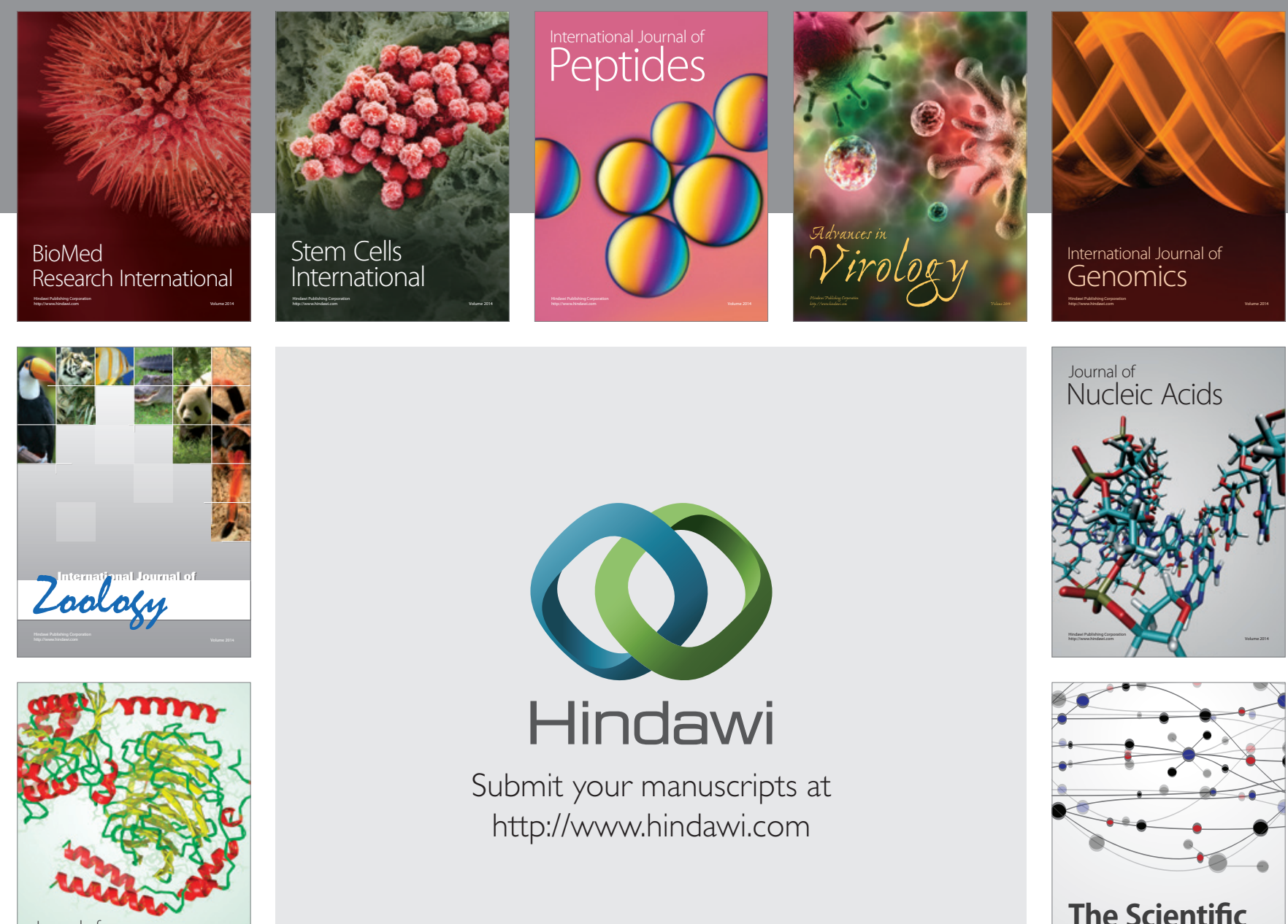

Submit your manuscripts at

http://www.hindawi.com

Journal of
Signal Transduction
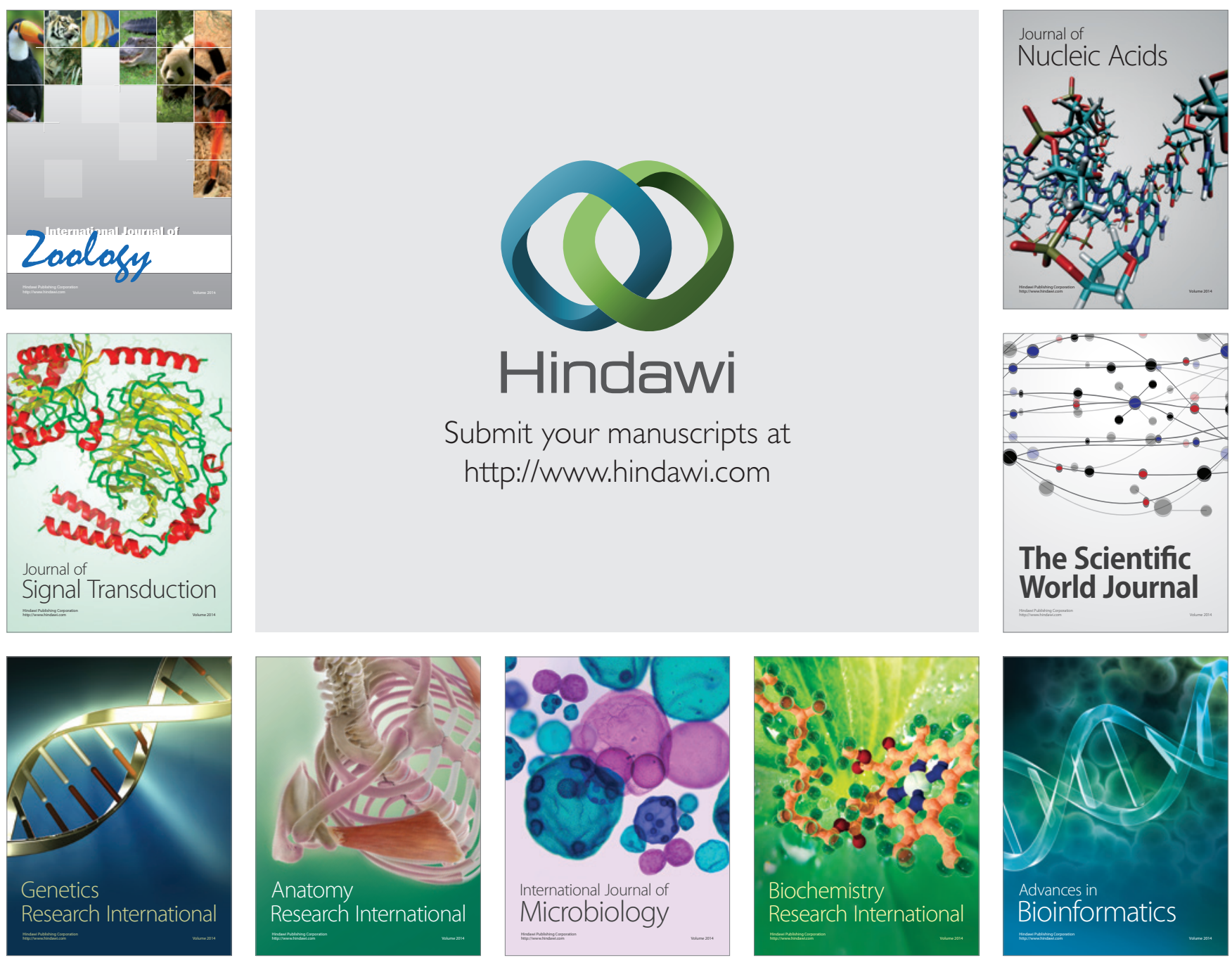

The Scientific World Journal
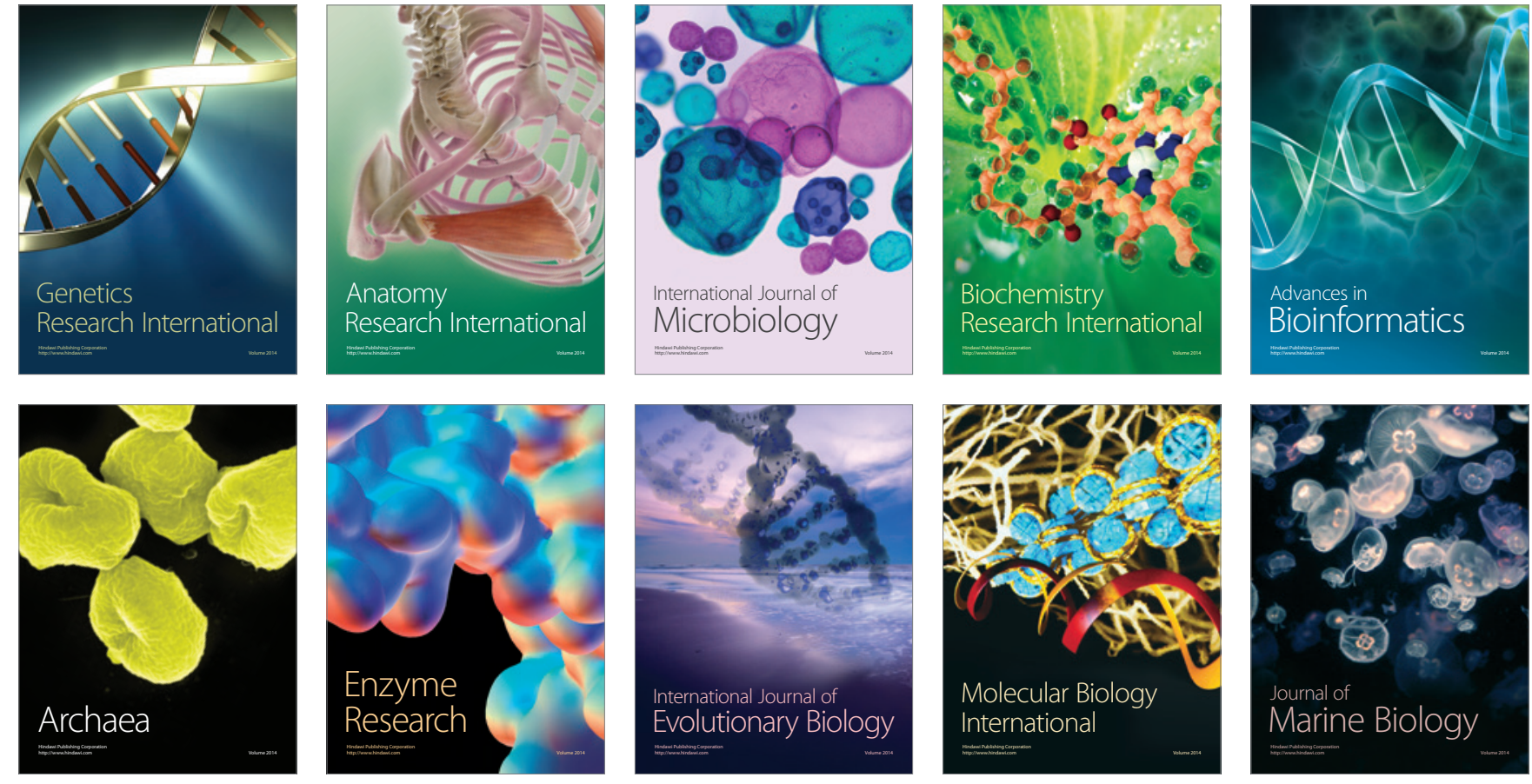